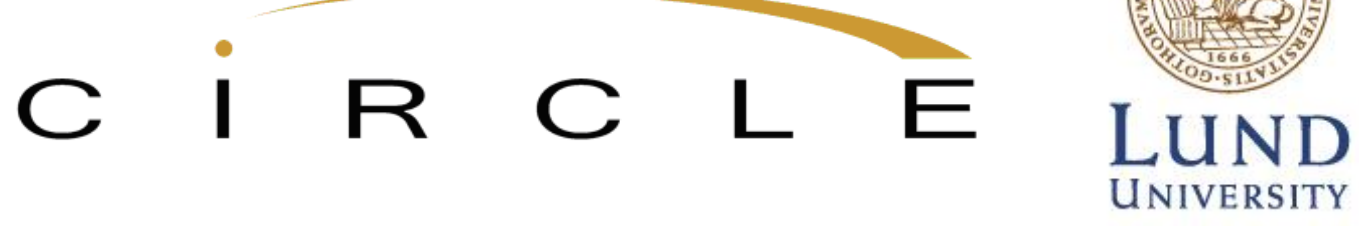

Paper no. 2013/21

On the link between urban location and the involvement of knowledge intensive business services firms in collaboration networks

Sverre J. Herstad (sverre.herstad@nifu.no) University of Agder

Bernd Ebersberger (bernd.ebersberger@mci.edu) MCl Management Center Innsbruck

This is a preprint of an article whose final and definitive form will be published in Regional Studies (c) [2013] [copyright Taylor \& Francis]; Regional Studies is available online at Taylor \& Francis ${ }^{\mathrm{TM}}$

http://www.tandfonline.com/toc/cres20/current\#.UbrTDfk3Aps.

Citations to and quotations from this work should reference that publication. If you use this work, please check that the published form contains precisely the material to which you intend to refer.

This version: June 2013

Centre for Innovation, Research and Competence in the Learning Economy (CIRCLE)

Lund University

P.O. Box 117, Sölvegatan 16, S-221 00 Lund, SWEDEN

http://www.circle.lu.se/publications 
WP 2013/21

On the link between urban location and the involvement of knowledge intensive business services firms in collaboration networks

Sverre J. Herstad and Bernd Ebersberger

\section{ABSTRACT}

Knowledge intensive business services firms can play a key role in modern economies by linking localized collaboration networks to global knowledge flows, and by actively serving in support of knowledge diffusion across institutional and sectoral divides. The extent to which they do is dependent on the markets, partners and human resources available locally. This paper uses the unique establishment-level innovation data available in Norway to investigate whether location in urban labour market regions influences the geographical scope of collaborative linkages maintained within and outside the realm of clients. It proceeds to consider whether the diversity of partner types used locally, domestically and abroad differ between locations.

JEL Code: L80, O31, R11

Keywords: knowledge intensive business services, urban economies, collaboration, internationalization,

Disclaimer: All the opinions expressed in this paper are the responsibility of the individual author or authors and do not necessarily represent the views of other CIRCLE researchers. 


\title{
On the link between urban location and the involvement of knowledge intensive business services firms in collaboration networks
}

\author{
Sverre J. Herstad \\ University of Agder, PO BOX 422, N-4604 Kristiansand, Norway; and NIFU, PO BOX 5183 Majorstuen, \\ $\mathrm{N}-0302$ Oslo, Norway. \\ Corresponding author. Mail to: sverre.herstad@nifu.no \\ Bernd Ebersberger \\ Management Center Innsbruck, Universitätsstraße 15, 6020 Innsbruck, Austria
}

May 2013

Forthcoming, Regional Studies

\begin{abstract}
Knowledge intensive business services firms can play a key role in modern economies by linking localized collaboration networks to global knowledge flows, and by actively serving in support of knowledge diffusion across institutional and sectoral divides. The extent to which they do is dependent on the markets, partners and human resources available locally. This paper uses the unique establishment-level innovation data available in Norway to investigate whether location in urban labour market regions influences the geographical scope of collaborative linkages maintained within and outside the realm of clients. It proceeds to consider whether the diversity of partner types used locally, domestically and abroad differ between locations.
\end{abstract}

Keywords: knowledge intensive business services, urban economies, collaboration, internationalization,

JEL: L80, O31, R11 


\section{Introduction}

Knowledge intensive business services firms (hereby refereed to only as KIBS) are positioned at the intersection between corporate demand for specialized knowledge, and the supply of this knowledge from various actors, institutions and locations. This means that KIBS can play a key role in modern economies by linking localized networks to global knowledge flows and by supporting knowledge diffusion across institutional and sectoral divides (Desroches \& Lepälä, 2011). The extent to which they fulfil this role depends on the number of different business contexts covered by the network linkages they maintain. This can be referred to as the geographical scope of networks (Fernhaber, Gilbert, \& McDougall, 2008). It also depends on the diversity of partner types used and thus cognitive domains covered, which can be referred to as their network breadth (Herstad, Bloch, Ebersberger, \& van de Velde, 2008; Laursen \& Salter, 2006). This paper is inspired by the notion that it is primarily KIBS in certain high-density urban agglomerations which exhibit behaviour conducive to such positioning (Wood, 2006). Hence, the paper seeks to investigate the legitimacy of this claim with particular emphasis on various aspects of internationalisation. In doing so, it addresses not only the question of whether urban economies influence the network behaviour of firms, but also how and why.

Methodologically, it extends the concepts of scope and breadth on the basis of recent contributions which have introduced the concept of network involvement (e.g. Ebersberger \& Herstad, 2013, Herstad, Aslesen \& Ebersberger, forthc). The empirical approach developed has two important advantages. First, this allows different locational impacts on the geographical scope of sales and various forms of innovation collaboration to be distinguished from each other. Second, it allows the breadth of collaborative linkages maintained at several spatial scales - locally, domestically outside own region and abroad - to be understood in relation to the background characteristics of the regional economy.

The empirical analysis uses establishment-level data for Norway, available through the Community Innovation Survey (CIS), to identify and delineate service-providing firms, establish the link between networking behaviour and various urban or non-urban labour market regions, and control for impacts on behaviour attributable to firm-specific characteristics such as size, IPR strategies and investments in innovation.

\section{Conceptual framework \& hypotheses}

Research on territorial innovation systems has traditionally put a strong emphasis on interactive learning by means of collaborative ties. This study is therefore not the first to consider potential relationships between locations and collaboration in various industries (Cumbers, MacKinnon, \& Chapman, 2003; Laursen, Masciarelli, \& Prencipe, 2012; Laursen, Reichstein, \& Salter, 2011). Yet, prior research is inconclusive with respect to the existence and strength of these relationships. Some studies have found positive associations between the density of related economic activity in an area and patterns of collaboration (Bennett, Robson, \& Bratton, 2001). In the context of services, it has been suggested that these linkages are particularly evident in sub-clusters of capital regions (Wood, 2006). Others claim that a direct relationship between urbanization and behaviour is far from apparent (Amin \& Thrift, 2002; Fritsch, 2003). Some have even argued that firms located in rural areas (Teirlinck \& Spithoven, 2008) or outside the capital region (Herstad, Pålshaugen, \& Ebersberger, 2011; Tödtling \& Trippl, 2005) may be more 'open' in their innovation processes. 
Despite this, no prior study has to our knowledge used large, representative-sample innovation micro data to investigate whether the networking behaviour of services firms differs systematically, and in a manner which reflects the resource conditions prevalent in their locations.

KIBS specialize in the creation, validation and application of specialized knowledge in order to solve client problems. They rely heavily on academic expertise blended with creativity, discretion and pragmatically justified rules of thumb, which reflect prior experiences and occupational norms (Faulconbridge, 2007; Robertson, Scarbrough, \& Swan, 2003). This knowledge is often complex and tacit, embodied in the minds of individual experts, and is provided to clients through direct interaction. This translates into 'inseparability' of service development, production and provision. It also generates unique loyalty problems, because proprietary knowledge cannot easily be stored, transported and provided in a disembodied form, separate from the on-going practices of individual experts (Alvesson, 2000; Dougherty, 2004). Knowledge intensive service provision is therefore considered highly localized, expert-dependent and client-oriented, in all aspects of its structure and its strategy.

These characteristics mean that non-local market presence and collaborative linkages of KIBS cannot be understood merely in terms of well-calculated responses to evolving external politicalinstitutional and technological circumstances, such as the inclusion of services in the GATT framework and the availability of modern ICTs (Javalgi, Griffith, \& White, 2004; Samiee, 1999). More fundamentally, these issues must be understood within the context of search processes and experience-based learning at the level of the individual expert and establishment. This is because the internationalization process itself leads to learning and subsequent changes in organisational routines and aims; internationalisation increases awareness of further international opportunities, leads to the adaptation of organizational routines conducive to the task of operating abroad, and changes the way risk-reward ratios are evaluated (Johanson \& Vahlne, 1977; Reihlen \& Apel, 2007).

Prior research on knowledge-intensive services includes the work of Coviello and Munro (1997), which reveals the role of initial contact points in forming the basis for a broader set of informal and formal ties. While more recent contributions disagree on the relative importance of formal business ties versus informal social ties, they do agree that relationships in place prior to the internationalization process are of importance in shaping it. For instance, recent work has found that the internationalization of UK consultancy firms is favourably influenced by founder networks established through prior career paths (Deprey, 2011; Deprey, Lloyd-Reason, \& Ibeh, 2011). Reihlen and Apel (2007) propose that internal cognitive diversity - the diversity of experiences among managers and other key employees - facilitates international opportunity identification and operations based on diverse knowledge inputs and market needs. This reflects the more general argument that proximity to a set of diverse, internationalized actors increases the likelihood that any individual firm conceives of operating in a foreign market (Fernhaber, et al., 2008).

The most important mechanisms for competence upgrading in KIBS is recruitment (Keeble \& Nachum, 2002). This occurs most intensively through local labour markets. The extent to which experts available in local labour markets have prior experience with international operations and maintain interpersonal networks that extend into foreign business contexts is influenced by the degree of internationalization among actors and institutions from which this recruitment occurs. Similarly, when a diverse set of actors and institutions constitute the recruitment basis, this is 
reflected not only in the diversity of experiences among new recruits, but also in the diversity of the external cognitive domains into which their informal network ties extend. Such networks are of vital importance to KIBS opportunity search (Robertson, et al., 2003; Todtling, Lehner, \& Trippl, 2006).

Urban economies merit special attention. This is partly due to the diversity of industrial activities, research, education and public administration functions concentrated within them, and partly due to the tendency of these to be simultaneously linked to international industrial, academic and public policy networks and to local service providers (Aslesen \& Isaksen, 2007; Aslesen \& Jakobsen, 2007; Simmie, 2003). From the perspective of KIBS, location in an urban economy is conducive to securing a broad knowledge supply base and enables demand specialization. Concentrations of KIBS are characterized by high and cluster-specific rates of inter-firm mobility (Aslesen, Isaksen, \& Stambøl, 2008; Herstad \& Ebersberger, 2012) by which knowledge accumulation becomes linked to regional 'occupational' labour markets (Lam, 2000). Such labour markets provide conditions for the rapid entry and exit of new actors and for intense spillovers between individual firms (Agrawal, Cockburn, \& McHale, 2006, Herstad, Sandven \& Solberg, 2013). By contrast, firms in peripheral regions face narrower local knowledge supply bases and local markets with less scope for specialization (O'Farrell, Zheng, \& Wood, 1996).

Firms in peripheral regions may compensate for these constraints by developing more innovative strategies and by attempting to 'internalize' some of the benefits which are external to firms in urban regions (Doloreux \& Shearmur, 2012). This may even out, or even reverse, the productivity differences which would be expected from differences in location characteristics (ibid). However, exposure to information which is valuable because it originates from outside the firm cannot, by definition, be fully replaced by internalization. Thus, the external resource base of urban locations provides location-specific support for the process of identifying and acting on extra-regional market opportunities. This should be reflected in the geographical scope of market presence and client collaboration, leading to the following first two hypothesis regarding KIBS and their locations:

\section{H1: Urban location is positively associated with geographically dispersed sales}

\section{H2: Urban location is positively associated with geographically dispersed client collaboration}

Client interaction is part and parcel of service provision and the threshold at which it becomes coproduction of knowledge is low. A substantial part of the literature has focused primarily on this dimension (Fosstenløkken, Løwendahl, \& Revang, 2003; Skjølsvik, Løwendahl, Kvålshaugen, \& Fosstenløkken, 2007). Yet, it is increasingly recognized that KIBS also engage in external knowledge sourcing beyond their client networks. Notably, the complementarities between demand and supply side linkages suggested by Castellacci (2010) are reflected in the notion of 'innovation value chains', wherein customers inspire new service development while knowledge from non-client actors enables it (Love, Roper, \& Bryson, 2011). Such innovation collaboration beyond the client base entails the externalization of individual experts' knowledge from the on-going practice of service provision (Dougherty, 2004). It therefore requires dedicated management attention and comes with distinct risks and opportunity costs. Furthermore, it requires mechanisms that ensure the appropriation of returns from the collaborative work at a later stage. However, management attention is a scarce resource (Ocasio, 1997) and the possibility to appropriate knowledge is often perceived as limited because the loyalty of individual experts cannot be taken for granted (von Nordenflycht, 2011). This increases the costs and the risks of collaboration. Hence, collaboration beyond the client base is 
selective and sensitive to the information flows and resources provided by the urban economy. This gives rise to a third hypothesis on the scope of collaboration:

H3: Urban location is positively associated with geographically dispersed non-client innovation collaboration

The sensitivity of collaboration to geographical distance is moderated by the quality and relevance of partners once they are identified (Laursen, et al., 2011). Nonetheless, proximity enables more frequent face-to-face interaction and trust that is conducive to the exploration and exchange of notyet-stable knowledge (Torre, 2008; Torre \& Rallett, 2005). Consequently, the diversity of potential partner firms and institutions available around an urban region firm translate into a locational advantage, which should be reflected in broad local collaboration. From this follows the first hypothesis on the breadth of collaborative linkages maintained:

H4: Urban location is positively associated with broad local innovation collaboration

Compared to firms in other regions, urban region KIBS face less severe trade-offs between quality, relevance, and proximity of collaboration partners. In institutionally thinner regions (Tödtling \& Trippl, 2005), KIBS have incentives to establish broader extra-regional collaboration networks (Doloreux \& Shearmur, 2012; O'Farrell, et al., 1996) in order to overcome local resource constraints, leading to the second hypothesis on collaboration breadth:

H5: Non-urban location is positively associated with broad extra-regional domestic innovation collaboration

However, the weaker access to specialized human resources and privileged information that is associated with institutional thinness may limit the ability of the firm to implement those strategies through which it compensates for locational constraints. As international involvement is particularly sensitive to information and resource constraints, a final hypothesis follows:

H6: Non-urban location is negatively associated with broad international innovation collaboration

These six hypotheses reflect the two intersections which are fundamental to knowledge intensive business service firms: The intersection between client and non-client actor groups, and the intersection between local and global knowledge networks. The key underlying assumption is that the context or location of a firm influences its positioning. In the following section these six hypotheses are tested in a manner which seeks to isolate locational influences from those influences attributable to individual firm characteristics and strategies. 


\section{Empirical analysis}

\section{Locations}

Previous empirical work using register data on housing and employment has identified 161 Norwegian labour market regions (Jukvam, 2002). These labour market regions are classified on a centrality scale ranging from 5 (capital region), through 4 (large city regions) to 1 (peripheral regions). Based on this, a comparison can be made between location in the capital region ('Capital') or the other three large city labour market regions ('Trondheim', 'Bergen', 'Stavanger') and those in a reference group consisting of labour market regions at centrality levels 1-3. This also allows us to distinguish urban economy influences from specific capital region influences. In order to capture whether these are specific to known services clusters within the capital region (e.g. Isaksen, 2008; Wood, 2006), the capital is split into three sub-regions. 'Capital C' captures locations within the capital city itself, and includes the main Norwegian financial centre. 'Capital $\mathrm{N}$ ' captures locations in the bordering north-eastern municipalities. 'Capital W' captures locations in the bordering southwestern municipalities, in which engineering and communication services are concentrated.

\section{Data, sample selection issues and estimation strategy}

The empirical analysis is based on micro-data from the sixth Norwegian Innovation Survey (CIS2008), collected by Statistics Norway in 2008 as an extended version of the harmonized European Community Innovation Survey (Eurostat, 2010; OECD, 2005). CIS data is collected by the national statistical agencies in all European countries on a biannual basis. The survey is based on the definitions of innovation input, behaviour and output laid out in the third edition of OECD's Oslo Manual (OECD, 2005). Innovation survey data is used for generating official innovation statistics for the EU and its member states. It has been used extensively for analysis in economics (e.g. Cassiman \& Veugelers, 2006; Cefis \& Marsili, 2006), management studies (e.g. Grimpe \& Kaiser, 2010; Laursen \& Salter, 2006) and economic geography (e.g. Ebersberger \& Herstad, 2012; Laursen, et al., 2011; Simmie, 2003).

In contrast to many other European countries, participation in CIS2008 was compulsory for the sampled Norwegian enterprises. This generated a comparatively large data set, which is not plagued by a non-response bias. The data has also been thoroughly reviewed and validated by Statistics Norway. Unique features of the Norwegian Innovation Survey include sampling for representativeness at the level of regions and the provision of basic information on all individual establishments within the surveyed enterprises. This information includes establishment size, sector and location. In total, the data set contains information on the innovation activities of 6,029 enterprises, with supplementary information on their 9,942 individual establishments within manufacturing industries, construction and infrastructure, wholesale trade and logistics, and knowledge-intensive business services. A total of 2,359 KIBS establishments are included in the data set. These are split into four sub-sectors: postal and communication services (NACE 64), technical services (NACE 72, 73), financial services (NACE 65-67) and other business services (NACE 74).

Only a sub-sample of observations is defined as innovation active and has provided information on these activities. As this might cause a selection bias (Heckman, 1979), regressions based on CIS are commonly estimated using a two-stage approach in which the second stage includes a control for unobserved determinants of selection estimated in the first stage (Crepon, Duguet, \& Mairesse, 
1998; Rammer, Czarnitzki, \& Spielkamp, 2009). In analysis at the level of regions, an additional sample selection issue arises from the level of sampling. The surveyed legal entity (the 'enterprise') may in fact consist of several operational entities (i.e. 'establishments') which i) may operate in different sectors and ii) be located in different regions. Consequently, when enterprises include more than one establishment, estimations on specific industries may be biased by the fact that the sectors of interest (e.g. knowledge intensive services) are not properly identified by the sectoral affiliation of the enterprise. Similarly, in estimations comparing regions, biases may result from discrepancies between the regions in which activities are actually conducted (by establishments) and regions in which they are reported (by enterprises). In the approach used here (see Figure 1), both biases have to be accounted for.

Figure 1 approximately here

The analysis uses individual establishment data to i) identify knowledge intensive business service providers through establishment-level sector codes and ii) estimate, by means of a selection equation, whether they are legally independent from other establishments and thus equal to the surveyed enterprise (Single $=1$ ). This stage is estimated by a probit regression on all 2,359 KIBS establishments identified (see figure 1):

Selection step one:

$$
\operatorname{Pr}\left(\text { Single }=\left.1\right|^{1} x_{i}\right)=\Phi\left({ }^{1} x_{i}{ }^{1} \beta\right)
$$

${ }^{1} x_{i}$ contains the variables capturing location (Trondheim, Stavanger, Bergen, and Capital), the size and the age of firms (measured in logarithmic scale) and their sub-sector affiliation. Based on this regression the Mills ratio is calculated and this is included in the subsequent regression steps to control for the selection bias.

By restricting this analysis to the 1,144 observations where the establishment equals the enterprise, it is possible to utilize the additional information available on the latter from CIS, to estimate the likelihood of innovation activity. This is necessary, because innovation collaboration can only be observed for those observations that are innovation active.

Selection Step two:

$$
\operatorname{Pr}\left(\text { Active }=\left.1\right|^{2} x_{i}\right)=\Phi\left({ }^{2} x_{i}^{2} \beta\right)
$$

In this step, ${ }^{2} x_{i}$ includes characteristics assumed to affect the decision to carry out innovation activities, including location (Trondheim, Stavanger, Bergen, and Capital) and sectoral indicators. Furthermore, weak prior growth should positively influence the propensity to engage in current innovation activity. The log of the average annual percentage growth rate, from start-up (or 2001 at the earliest) until the start of the CIS reference period in 2006, is calculated based on business register data and is included. As affiliation with a foreign corporate group may either enable innovation activity or constrain it (Cantwell \& Mudambi, 2005; Frenz \& letto-Gillies, 2007), a control 
for this is included. By the same token, foreign market presence entails larger market size and exposure to more diverse information. Because this may influence the decision to engage in innovation activities (Crepon, et al., 1998), ${ }^{2} x_{i}$ includes a dummy variable capturing whether the main market is foreign. Based on this selection regression a second Mills ratio is computed, which will be included in the final outcome regression.

The correction of selection biases by means of the three step model employed here requires two instruments to produce credible estimates. In each stage, at least one variable has to determine selection without affecting any of the subsequent stages (Greene, 2000; Puhani, 2000).

Establishment age is used as the instrument in the first step. Age should reduce the likelihood that the focal establishment is legally independent from other establishments, but should not affect the decision to engage in innovation activity or collaborate in various forms (e.g. Wong \& He, 2009). In the second stage, the growth rate is included as an additional instrument. It should affect the decision to engage in innovation activities, but should not affect collaborative involvement.

The results of the selection equations are reported in Table A1 in the appendix. Age and size, measured as their respective natural logarithms, significantly reduce the likelihood that the establishment fully equals the enterprise surveyed by CIS. The strong, positive impact of capital region location is notable because no significant impacts are detected from location in any of the other urban labour market regions. Location in the capital region significantly reduces the likelihood of innovation activity, while location in the second largest town of Bergen significantly increases it. This is consistent with the notion that knowledge spillovers between KIBS in the capital region are reducing their individual incentive to engage in systematic development work due to appropriability problems and the option of 'learning-by-hiring' provided by the strong regional labour markets for expertise (e.g. Herstad, et al., 2011, Herstad \& Ebersberger, 2012).

\section{Outcome regressions}

\section{Scope and breadth of collaborative involvement}

The innovation survey specifies four geographical levels at which the firm can have a market presence (locally and non-locally in Norway, in EU or EFTA countries, and elsewhere). Furthermore, it specifies a total of eight potential collaboration partner groups, which range from downstream customers through suppliers and competitors, into research institutes and universities upstream. For each partner group, the firm indicates whether a collaborative interaction has taken place in its own region (subjectively defined by the firm itself), elsewhere in Norway or in either one of five world regions specified (Nordic countries, EU excl. Nordic countries, North America, Asia, other).

Based on this, a set of indicators can be constructed which capture the geographical scope of involvement in sales, client collaboration and non-client collaboration. An additional set of indicators captures the breath of collaborative involvement locally, domestically outside own region, and abroad. To estimate the scope of involvement the information available on the geographical location of the given types of collaboration partners (clients or non-client actor groups specified in the questionnaire) was used. The breadth of involvement was calculated using the information available on the different types of collaboration partners at the three main spatial levels specified. The raw 
involvement indexes developed in this study are constructed in accordance with the work of Bozeman, Gaughan and Corley (Bozeman \& Gaughan, 2011; Gaugan \& Corley, 2010) as weighted additive indices. The weights are the inverse of the relative frequency of the activity in the NACE 2digit sector'. All involvement indexes are log transformed prior to estimations.

\section{Estimation}

It cannot be assumed that the decision to engage along one dimension is independent of activities along other dimensions. Two sets of seemingly unrelated regressions with three dependent variables each are therefore estimated (Zellner, 1962):

$$
\begin{aligned}
& v_{1 i}={ }^{3} x_{j}{ }^{3} \beta_{1}+u_{1 j} \\
& v_{2 i}={ }^{3} x_{j}{ }^{3} \beta_{2}+u_{2 j} \\
& v_{3 i}={ }^{3} x_{j}{ }^{3} \beta_{3}+u_{3 j}
\end{aligned}
$$

where $u=\left(u_{1}^{\prime}, u_{2}{ }^{\prime}, u_{3}{ }^{\prime}\right)^{\prime}$ and $E(u)=0, E\left(u u^{\prime}\right)=\Sigma$.

The first set of regressions estimates involvement in geographically dispersed sales $\left(v_{1}\right)$ client collaboration $\left(v_{2}\right)$ and non-client collaboration $\left(v_{3}\right)$, whereas the second set of regressions estimates the breadth of involvement in regional collaboration $\left(v_{1}\right)$, domestic collaboration $\left(v_{2}\right)$ and international collaboration $\left(v_{3}\right)$. The Breusch-Pagan Chi2 Lagrange multiplier test (Breusch \& Pagan, 1980 ) is implemented to capture interdependencies between the outcome variables revealed by the correlation of their error terms (Arora, 1996). All outcome regressions are reported in a base form, which includes only locations, selection controls and instruments; and in a full form which includes all exogenous variables.

\section{Control variables}

CIS data allows a number of control variables to be implemented in order to isolate the impact of firm-specific characteristics from the impact of the location itself. First, increasing firm size typically entails more diverse competences, stronger management capabilities and better developed organizational systems (e.g. Gilbert, McDougall, \& Audretsch, 2006). On the other hand, firms of a smaller may exhibit increased organizational flexibility and dependence on resources in their external environments (Fernhaber, et al., 2008). Consequently, size may either increase the propensity of the firm to collaborate, due to management learning and organizational absorptive capacity effects, or may reduce this propensity due to less flexibility and the lower dependence on external resources which follow from stronger internal capabilities. As this suggests a certain non-linearity, enterprise size is controlled for by comparing small establishments ( $<26$ employees) and large establishments (>99 employees) to a reference group consisting of medium sized establishments.

Innovation expenditures (R\&D and non-R\&D) measured in NOK 100000 per employee are used to capture the firm's emphasis on systematic new knowledge development (Ebersberger, Herstad, Iversen, Som, \& Kirner, 2011; Tether, 2002). A strong emphasis on innovation strengthens internal knowledge resources and routines and in this way can increase the capacity to engage in collaborative work (Cohen \& Levinthal, 1989, 1990), in particular over long distances (de Jong \& Freel, 2009). A control for innovation intensity is included, in order to capture these effects. The 
networks of foreign enterprise groups may serve as a channel for international sales and collaboration partner search, in a manner not attributable to the location of the individual firm (Asheim, Ebersberger, \& Herstad, 2012; Kafouros, Buckley, \& Clegg, 2012). However, such affiliation also requires attention, potentially at the expense of attention towards collaborative knowledge development (Blanc \& Sierra, 1999; Ebersberger \& Herstad, 2012). A control is therefore included which captures foreign group affiliation. Public innovation funding schemes often aim to achieve behavioural additionally (Czarnitzki, Ebersberger, \& Fier, 2007). This effect is controlled for by a dummy variable on the receipt of domestic or EU funding. Lastly, because collaborative work involves exposure of proprietary knowledge, willingness to engage is likely to be contingent on the availability of relevant IPR protection measures. The control for IPR breadth (Herstad, et al., 2008) captures the fraction of specified IPR protection mechanisms (patents, industrial designs, trademarks, copyright, secrecy, complexity of goods and services and lead time advantages) which the establishment reports using.

In the last set of regressions, each equation includes a control for the market presence, which corresponds to the level of involvement captured by the dependent variable. This procedure is applied to specifically capture the strength of the linkage between KIBS market presence at a certain geographical level, and their involvement at the same level. Bivariate correlations and descriptive statistics for all variables are reported in Table A2 in the appendix. 


\section{Results}

Table 1 below shows the results of the regressions on the geographical scope of involvement in sales, client collaboration and non-client collaboration. The base model detects a more dispersed market presence among KIBS located in the fourth largest labour market region of Stavanger, compared to the more peripheral reference regions (centrality 1-3). This effect loses significance when the control variables are included. By contrast, the full model finds that KIBS in the second and third largest labour market regions (Bergen and Trondheim) are less involved in geographically dispersed sales than KIBS located outside the large city regions. Thus, peripherality rather than urban location is associated with broader market presence.

Table 1 approximately here

Neither an urban location in general, nor a capital region location in particular, increases the scope of demand side involvement. The fact that neither hypothesis $\mathrm{H} 1$ nor hypothesis $\mathrm{H} 2$ is supported suggests that the outward push to reach extra-regional markets experienced by KIBS in peripheral regions is as strong as the enabling effect of resources specific to urban regions. In contrast, the base and full models estimating involvement in geographically dispersed non-client collaboration yield highly significant coefficients for all three capital region sub-clusters (Capital C, Capital N, and Capital W). The negative impacts of location in the other large city regions on both non-client and client side involvement are not significant, either individually or jointly. Thus, the support for Hypothesis H3 is specific to the capital region.

The Breusch-Pagan test reveals that independence of the three forms of involvement can be rejected (Chi2=237, 18; $p=0,000)$. Notable control variable impacts include positive and highly significant parameter estimates for innovation intensity in all three equations. Furthermore, foreign group affiliation increases involvement in geographically dispersed sales, but has negative, although insignificant, effects on involvement in collaboration. As expected, public funding is positively associated with collaborative involvement. Supplementary Wald tests reveal that the impact of public funding on non-client involvement is not significantly stronger than any individual capital region variable impact. At the outset, this means that merely 'being there' in the capital has an impact on collaboration, which is approximately equal to the behavioural additionality of public funding. Lastly, neither small nor large KIBS are more involved than medium-sized KIBS establishments (the reference group); nor are the coefficients for small and large size, according to Walds tests, significantly different from each other.

The regressions on the breadth of involvement at different geographical levels are reported in Table 2. In the full model, it is only capital region location which is associated with stronger involvement locally and abroad. Notably, this holds even after controlling for whether or not the firm is present in local and international markets respectively. It is only the breadth of foreign involvement which is influenced significantly by market presence at the same spatial level. Thus, the conditional (on capital region location) support for Hypothesis H4 suggests that while KIBS in this region actively draw on a broad range of local collaboration partners, KIBS in other urban labour market regions do not do so to the same extent. Similarly, the conditional (on capital region location) support for Hypothesis $\mathrm{H} 6$ is consistent with the findings on the scope of non-client linkages: Capital region KIBS actively use the 
local resource base while searching for and collaborating with international partners. In fact, supplementary Wald's tests reveal that breadth of foreign involvement is significantly more strongly influenced by merely 'being there' in the central or western services clusters of the capital, than it is influenced by foreign market presence ( $C h i 2=3.52$ and $4.56, p=0.065$ and 0.032 respectively).

The full model that estimates the breadth of non-local domestic collaboration yields significantly negative coefficient estimates for all urban locations, except for the capital. This provides support for Hypothesis $\mathrm{H} 5$, which predicts broader non-local domestic involvement outside urban regions due to local resource constraints. The fact that it takes the form of significant differences between peripheral regions and non-capital urban regions only points to the dominant position of the capital region economy in the national innovation system as a whole. It also raises the question of whether domestic collaboration networks of KIBS in peripheral regions by and large converge on the capital.

\section{Table 2 approximately here}

The Breusch-Pagan test again finds that independence can be rejected (Chi2 $=328,543 ; p=0,000$ ). Furthermore, the analysis finds small KIBS to be more involved abroad than medium-sized KIBS and a negative coefficient for large KIBS. While the latter is not significant, this does suggests that internationalization is influenced by receptiveness to external opportunities. This receptiveness exerts a stronger influence than the managerial capabilities and broader internal competences which typically are associated with size.

\section{Conclusion}

This paper has investigated whether the resources available to KIBS in urban locations influence the scope and breadth of their collaborative involvement. In doing so, it has also analysed the role played by services in linking localized collaboration networks to global knowledge flows, and in contributing to knowledge diffusion across institutional and sectoral divides. The provision of advanced business services is fundamentally a process of knowledge coproduction with clients. Consequently, the geographical scope of client collaboration is closely linked to the geographical scope of market presence, and to the overall emphasis put on innovation by the individual firm. Resources available to KIBS in urban regions may make it easier for them to identify and pursue extra-regional market opportunities, as suggested in the theoretical discussion, but these effects are overshadowed by the stronger external market dependence of KIBS outside these regions.

Partnerships which extend beyond the realm of clients are also closely associated with firm-specific investments in innovation. However, compared to demand side relationships, they are much more selective and subjected to stronger partner search, opportunity cost and human resource constraints. These constraints are mediated by competences and contact points to informal networks provided by individual experts, or those accessed through pre-existing collaborative ties (Johanson and Vahlne, 2009). The result is significantly stronger non-client involvement amongst KIBS in those capital region locations which offer the greatest direct access to human resources and the most diverse local partner base. 
In other words, the commitment of capital region KIBS to local collaboration reflects the placespecific availability of resources which also support broader, and more far-reaching, international involvement. This underscores how network linkages internal and external to locations may be complementary to each other (Bathelt, Malmberg \& Maskell, 2004) rather than contradictory (e.g. Fitjar \& Rodríguez-Pose, 2012) in their impact on territorial industrial dynamics: Strong international involvement amongst individual firms and public sector institutions translates into broad local economy contact points to non-local networks, and the build-up of experience with international operations amongst potential partner firms and professionals mobile in occupational labour markets. This allows technology and market opportunities external to the region to be identified and pursued by firms which, at the outset, primarily focus on search and client collaboration within it. The diverse and internationalized industrial base of the capital region thus enables service providers to continuously emerge, reflect on and redefine their own positioning at the intersection between knowledge supply and knowledge demand, the global and the local (Wood, 2006). As they do so, they collectively expand the local resource base available to other firms to support their establishment of broad and far-reaching network linkages.

The self-reinforcing advantageous position of the capital as a breeding ground for internationalized services raises questions concerning the need for policy intervention. In non-urban Norwegian labour market regions, it is apparent that weak local resource bases translate into a strong dependence on domestic collaboration networks which, to unknown degrees, converge on the capital. To the extent that governmental initiatives should target KIBS in these regions, they should focus on supporting the build-up of internal competences and on strengthening their international linkages (Herstad, Bloch, Ebersberger \& van De Velde, 2010). Both these aspects of KIBS activity are constrained by occupational labour markets which reflect comparatively weak industrial bases and brain drain towards the capital (Aslesen et. al., 2008). Nonetheless, the inherent dependence of KIBS on surrounding local conditions suggests that the potential for growth in peripheral regions is limited, and is more dependent on effective regional innovation policies as a whole than on initiatives aimed specifically at services.

A need for targeted intervention is more evident in the non-capital urban regions, where colocation with advanced industrial organizations and knowledge institutions does not trigger significantly broader local commitment than that found in peripheral regions. This merits attention in the form of local mobilization and networking initiatives (Tödtling \& Trippl, 2005), because the KIBS sector appears unable to exploit the diverse knowledge assets and capabilities which are present. Even more importantly, it entails that the sector does not to live up to its potential for actively contributing to cross-fertilization between them.

Certain important limitations to the study must be acknowledged. First, cross-sectional data cannot be used to determine whether innovation policies and associated funding schemes actively influence the positioning of KIBS within the nexuses of global-local and demand-supply, or merely follow up with funding once such positions are already established. A second limitation is that the data does not allow analyses of the purpose and content of various collaborative linkages, nor how they evolve over time. This means that the analyses cannot describe the nature of demand side linkages maintained at various spatial scales, nor capture the relationship between demand and supply side involvement. It also cannot describe what is likely to be a distinct division of labour between local linkages, motived by the resources available in the capital, and international collaboration, motived 
by a need to access resources which are not. This underscores how further quantitative and qualitative analyses is needed to capture the evolutionary dynamics of new service firm formation and network positioning, and how innovation policies may directly or indirectly influence these dynamics under different regional conditions.

Third, the empirical analysis has assumed that the use of public funding schemes, the overall emphasis put by KIBS on innovation and their implementation of IPR protection strategies are microlevel characteristics determined independently of locations. This assumption is not trivial. Access to public innovation schemes may, due to the incorporation of regional development objectives, be contingent on the location of the firm. Furthermore, innovation intensity and IPR strategies may, like the decision to engage in innovation activity, be influenced by regional economy characteristics and by the local appropriability regimes these characteristics give rise to (Herstad \& Ebersberger, 2012, Herstad et. al., 2011).

The Norwegian capital region is, by international standards, small and peripheral. Despite this, it does exhibit the concentration of knowledge workers, private sector R\&D and business services which is typical of such regions. Limitations attributable to the use of data from a single, small, open economy should therefore not overshadow the fact that the analysis provided herein has, as the first of its kind, pin-pointed the types of collaborative linkages that are sensitive to influences from high-density urban locations. This is an important contribution in its own right, which also allows for an improved understanding of how the concentration of services in such locations both expresses and expands their role as 'melting pots' for information and knowledge originating in various institutional and geographical domains. It follows that the growth of internationally oriented services may not so much be a general urban economy phenomenon, as a phenomenon which is, and likely will remain, contained within the very limited number of locations positioned for such growth at the outset.

\section{Acknowledgements}

Research for this article was funded by the Research Council of Norway under the project 'Economic Development Paths in Norwegian Regions', and inspired by work previously conducted by the authors under the Councils 'Programme for Regional R\&D and Innovation' (VRI). The financial support received, and the valuable input provided by two anonymous reviewers and the Editors, is gratefully acknowledged. Yet, the usual disclaimers apply. 


\section{References}

Agrawal, A., Cockburn, I., \& McHale, J. (2006). Gone but not forgotten: knowledge flows, labor mobility, and enduring social relationships. Journal of Economic Geography, 6(5), 571-591.

Alvesson, M. (2000). Social identity and the problem of loyalty in knowledge-intensive companies. Journal of Management Studies, 37(8), 1101-1123.

Amin, A., \& Thrift, N. (2002). Cities. Reimagining the urban. Cambridge: Polity Press.

Arora, A. (1996). Testing for complementarities in reduced-form regressions: A note. Economics Letters, 50(1), 51-55.

Asheim, B. T., Ebersberger, B., \& Herstad, S. (2012). MNCs between the global and the local: Knowledge bases, proximity and distributed knowledge networks. In M. Heidenreich (Ed.), Innovation and institutional embeddedness of multinational companies (pp. 77-104). Cheltenham: Edward Elgar.

Aslesen, H. W., \& Isaksen, A. (2007). Knowledge intensive business services and urban industrial development. Service Industries Journal, 27(3), 321-338.

Aslesen, H. W., Isaksen, A., \& Stambø|, L. S. (2008). Knowledge intensive business services as innovation agent through client interaction and labour mobility. International Journal of Services Technology and Management, 9(2), 138-153.

Aslesen, H. W., \& Jakobsen, S. E. (2007). The role proximity and knowledge interaction between head offices and KIBS. Tijdschrift voor Economische en Sociale Geografie, 98(2), 188-201.

Bathelt, H., Malmberg, A., \& Maskell, P. (2004). Clusters and Knowledge: Local Buzz, Global Pipelines and the process of knowledge creation. Progress in Human Geography, 28(1), 31-56.

Bennett, R., Robson, P., \& Bratton, W. (2001). The influence of location on the use by SMEs of external advice and collaboration. Urban Studies, 38(9), 1531-1557.

Blanc, H., \& Sierra, C. (1999). The internationalisation of R\&D by multinationals: A trade-off between external and internal proximity. Cambridge Journal of Economics, 23 (2) 187-206.

Breusch, T. S., \& Pagan, A. R. (1980). The Lagrange multiplier test and its applications to model specification in econometrics. Review of Economic Studies, 47, 239-253.

Cantwell, J., \& Mudambi, R. (2005). MNE Competence-Creating Subsidiary Mandates. Strategic Management Journal, 26(12), 1109-1128.

Cassiman, B., \& Veugelers, R. (2006). In search of complementarity in innovation strategy: Internal $R \& D$ and external knowledge aquisition. Management Science, 52(1), 68-82.

Castellacci, F. (2010). The internationalization of firms in the service industries: Channels, determinants and sectoral patterns. Technological Forecasting and Social Change, 77(3), 500513.

Cefis, E., \& Marsili, O. (2006). Survivor: The role of innovation in firms' survival. Research Policy, 35(626-641).

Cohen, W. M., \& Levinthal, D. A. (1989). Innovation and learning: The two faces of R\&D. Economic Journal, 99(397), 569-596.

Cohen, W. M., \& Levinthal, D. A. (1990). Absorptive capacity - a new perspective on learning and innovation. Administrative Science Quarterly, 35(1), 128-152.

Coviello, N. E. (2006). The Network Dynamics of International New Ventures. Journal of international Business Studies, 37(5), 713-731.

Coviello, N. E., \& Munro, H. J. (1997). Network relationships and the internationalization process of small software firms. International Business Review, 6(4), 361-386.

Crepon, B., Duguet, E., \& Mairesse, J. (1998). Research, innovation, and productivity: An econometric analysis at the firm level. Economics of Innovation and New Technology, 7, 115-158.

Cumbers, A., MacKinnon, D., \& Chapman, K. (2003). Innovation, collaboration, and learning in regional clusters: a study of SMEs in the Aberdeen oil complex. Environment and Planning $A$, $35,1689-1706$. 
Czarnitzki, D., Ebersberger, B., \& Fier, A. (2007). The relationship between R\&D collaboration, subsidies and R\&D performance: Empirical evidence from Finland and Germany. Journal of Applied Econometrics, 22, 1347-1366.

de Jong, J. P. J., \& Freel, M. (2009). Absorptive capacity and the reach of collaboration in high technology small firms. Research Policy, 39(1), 47-54.

Deprey, B. D. (2011). The internationalisation process of small and medium-sized management consultancies in the UK. Doctor of Philosophy Thesis, Anglia Ruskin University.

Deprey, B. D., Lloyd-Reason, L., \& Ibeh, K. I. N. (2011). The internationalization of small and mediumsized management consultancies: an exploratory study of key facilitating factors. The Service Industries Journal, 32(10), 1609-1621.

Desroches, P., \& Lepälä, S. (2011). Opening up the 'Jacobs Spillovers' black box: Local diversity, creativity and the processes underlying new combinations. Journal of Economic Geography, doi:10.1093/jeg/lbq028.

Doloreux, D., \& Shearmur, R. (2012). Collaboration, information and the geography of innovation in knowledge intensive business services. Journal of Economic Geography, 12, 79-105.

Dougherty, D. (2004). Organizing practices in services: Capturing practice-based knowledge for innovation. Strategic Organization, 2(1), 35-64.

Ebersberger, B., \& Herstad, S. (2012). Go abroad or have strangers visit? On organizational search spaces and local linkages Journal or Economic Geography 12(1), 273-295.

Ebersberger, B., \& Herstad, S. (2013). The relationship between international innovation collaboration, intramural R\&D and SME's innovation performance: A quantile regression approach. Applied Economic Letters, 20(7), 626-630.

Ebersberger, B., Herstad, S., Iversen, E., Som, O., \& Kirner, E. (2011). Open innovation in Europe. Brussels: European Commission, DG Enterprise and Industry.

Ellis, P. (2000). Social Ties and Foreign Market Entry. Journal of international Business Studies, 31(3), 443-469.

Faulconbridge, J. R. (2007). Exploring the role of professional associations in collective learning in London and New York's advertising and law professional-service-firm clusters. Environment and Planning A, 39, 965 - 984.

Fernhaber, S. A., Gilbert, B. A., \& McDougall, P. P. (2008). International entrepreneurship and geographic location: An empirical examination of new venture internationalization. Journal of International Business Studies, 39, 267-290.

Fitjar, R. D., \& Rodríguez-Pose, A. (2012). Firm collaboration and modes of innovation in Norway. Research Policy, 42(1), 128-138.

Fosstenløkken, S., Løwendahl, B. R., \& Revang, Ø. (2003). Knowledge development through client interaction: A comparative study. Organization Studies, 24(6), 859-879.

Frenz, M., \& letto-Gillies, G. (2007). Does multinationality affect the propensity to innovative? An analysis of the Third Community Innovation Survey International Review of Applied Economics, 21(1), 99-117.

Fritsch, M. (2003). Does R\&D Cooperation Behavior Differ between Regions? Industry \& Innovation, 10(1), 25 - 39.

Gilbert, B. A., McDougall, P. P., \& Audretsch, D. B. (2006). New venture growth: A review and extension. Journal of Management, 32(6), 926-950.

Greene, W. H. (2000). Econometric Analysis (4 ed.). Upper Saddle River: Prentice Hall

Grimpe, C., \& Kaiser, U. (2010). Balancing Internal and External Knowledge Acquisition: The Gains and Pains from R\&D Outsourcing. Journal of Management Studies, 47(8), 1483-1509.

Heckman, J. J. (1979). Sample selection bias as a specifcation error. Econometrica, 47(1), 153-161.

Herstad, S., Bloch, C., Ebersberger, B., \& van De Velde, E. (2010). National innovation policy and global open innovation: Exploring trade-offs, balances and complementarities. Science and Public Policy, 37(2), 113-124.

Herstad, S., Bloch, C., Ebersberger, B., \& van de Velde, E. (2008). Open innovation and globalisation: Theory, evidence and implications. Helsinki: VISION Eranet. 
Herstad, S., \& Ebersberger, B. (2012). Knowledge intensive business services, innovation activity and the capital region economy. Mimeo. Oslo: NIFU.

Herstad, S., Sandven, T., \& Solberg, E. (2013). Location, education and enterprise growth. Applied Economics Letters, 20(10), 1019-1022.

Herstad, S., Pålshaugen, $\varnothing$., \& Ebersberger, B. (2011). Industrial innovation collaboration in a capital region context. Journal of the Knowledge Economy, 2(4), 507-532.

Herstad, S., Aslesen, H. W., \& Ebersberger, B. (Forthc.). On industrial knowledge bases, commercial opportunities and global innovation network linkages. Accepted for publication, Research Policy.

Isaksen, A. (2008). The clustering of software consultancy in Oslo. In C. Karlsson (Ed.), Handbook of Research on Innovation and Clusters. Cheltenham: Edward Elgar.

Javalgi, R., Griffith, D., \& White, S. (2004). An empirical examination of factors influencing the internationalization of service firms. The Journal of Services Marketing, 17(2), 185-201.

Johanson, J., \& Vahlne, J. E. (1977). The internationalization process of the firm: A model of knowledge development and increasing foreign market commitments. Journal of International Business Studies, 8(1), 23-32.

Johanson, J., \& Vahlne, J. E. (2009). The Uppsala internationalization process model revisited: From liability of foreigness to liability of outsidership. Journal of international Business Studies, 40, 1411-1431.

Jukvam, D. (2002). Defining labour market regions. Oslo: Norwegian Institute for Urban and Regional Research.

Kafouros, M. I., Buckley, P. J., \& Clegg, J. (2012). The effects of global knowlege reservoirs on the productivity of multinational enterprises: The role of international breadth and depth. Research Policy, 41, 848-861.

Keeble, D., \& Nachum, L. (2002). Why do business service firms cluster? Small consultancies, clustering and decentralization in London and southern England. Transactions of the Institute of British Geographers, 27(1), 67-90.

Lam, A. (2000). Tacit knowledge, organizational learning and innovation: A societal perspective. Organization Studies, 21(3), 487-513.

Laursen, K., Masciarelli, F., \& Prencipe, A. (2012). Regions matter: How localized social capital affects innovation and external knowledge aquisition. Organization Science, 23(1), 177-193.

Laursen, K., Reichstein, T., \& Salter, A. (2011). Exploring the Effect of Geographical Proximity and University Quality on University-Industry Collaboration in the United Kingdom. Regional Studies, 45(4), 507-523.

Laursen, K., \& Salter, A. (2006). Open for innovation: The role of openness in explaining innovation performance among UK manufacturing firms. Strategic Management Journal, 27 (2) 131-150.

Love, J. H., Roper, S., \& Bryson, J. R. (2011). Openness, knowledge and growth in UK business services. Research Policy, 40, 1438-1452.

O'Farrell, P. N., Zheng, J., \& Wood, P. A. (1996). Internationalization of Business Services: An Interregional Analysis. Regional Studies, 30(2), 101 - 118.

Ocasio, W. (1997). Towards an attention-based view of the firm. Strategic Management Journal, 18, 187-206.

Puhani, P. A. (2000). The Heckman correction for sample selection and its critique. Journal of Economic Surveys, 14(1), 53-68.

Rammer, C., Czarnitzki, D., \& Spielkamp, A. (2009). Innovation success of non-R\&D-performers: substituting technology by management in SMEs. Small Business Economics, 33(1), 35-58.

Reihlen, M., \& Apel, B. A. (2007). Internationalization of professional services firms as learning: A constructivist approach. International Journal of Service Industry Management, 18(2), 140151.

Robertson, M., Scarbrough, H., \& Swan, J. (2003). Knowledge creation in professional service firms: Institutional effects. Organization Studies, 24(6), 831-857. 
Samiee, S. (1999). The internationalization of services: trends, obstacles and issues. The Journal of Services Marketing, 13(4-5), 319-336.

Simmie, J. (2003). Innovation and urban regions as national and international nodes for the transfer and sharing of knowledge. Regional Studies, 37(6-7), 607-620.

Skjølsvik, T., Løwendahl, B. R., Kvålshaugen, R., \& Fosstenløkken, S. M. (2007). Choosing to learning and learning to choose: Strategies of client co-prodution and knowledge development. California Management Review, 49(3), 110-128.

Storper, M., \& Venables, A. J. (2004). Buzz: face-to-face contact and the urban economy. Journal of Economic Geography, 4(4), 351-370.

Teirlinck, P., \& Spithoven, A. (2008). The spatial organization of innovation: Open innovation, external knowledge relations and urban structure. Regional Studies, 42(5), 689-704.

Tether, B. S. (2002). Who co-operates for innovation and why? An empirical analysis. . Research Policy, 31, 947-967.

Torre, A. (2008). On the role played by temporary geographical proximity in knowledge transmission. Regional Studies, 42(6), 869-889.

Torre, A., \& Rallett, A. (2005). Proximity and localization. Regional Studies, 39(1), 47-59.

Tödtling, F., \& Trippl, M. (2005). One size fits all? Towards a differentiated regional innovation policy approach. Research Policy, 34 (8) 1203-1219.

Tödtling, F., Lehner, P., \& Trippl, M. (2006). Innovation in knowledge intensive industries: The nature and geography of knowledge links. [Article]. European Planning Studies, 14(8), 1035-1058.

von Nordenflycht, A. (2011). What is a professional service firm? Towards a theory and a taxonomy of knowledge-intensive firms. Academy of Management Review, 35(1), 155-174.

Wong, P. K., \& He, Z. L. (2009). The impacts of knowledge interaction with manufacturing clients of knowledge-intensive business services firms. Innovation: Management, Policy \& Practice, 11(3), 264-278.

Wood, P. (2006). Urban development and knowledge-intensive business services: Too many unanswered questions? Growth and Change, 37(3), 335-361.

Zellner, A. (1962). An efficient meothod for estimating seemingly unrelated regressions and tests for aggregation bias. Journal of the American Statistical Association, 57, 348-368. 
Herstad \& Ebersberger, May 2013

\section{Appendix}

\section{Tables $A 1$ and $A 2$ here}




\section{Figures}

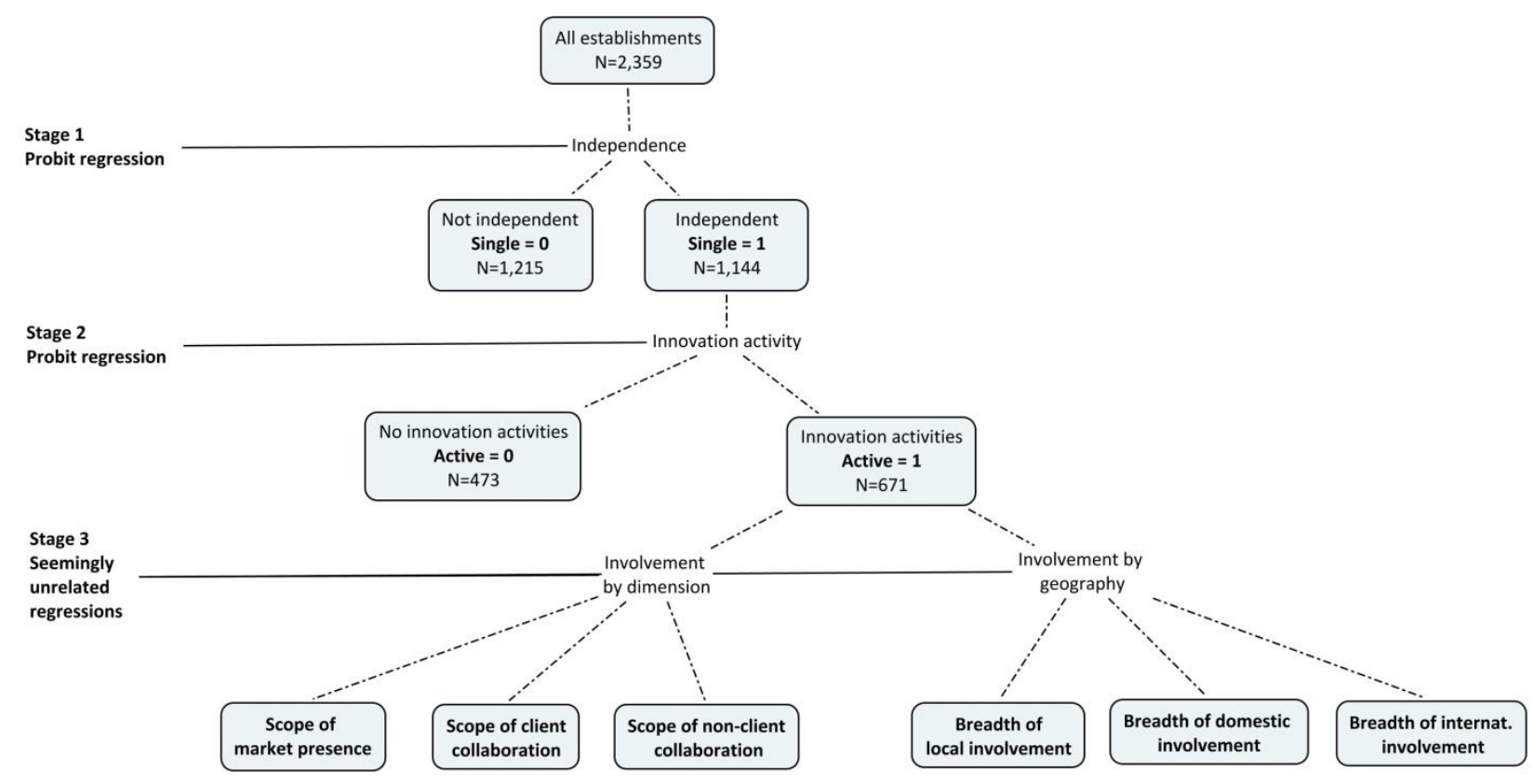




\section{Tables}

Table 1: Involvement by dimension

\begin{tabular}{|c|c|c|c|c|c|c|c|c|c|c|c|c|}
\hline & \multicolumn{12}{|c|}{ Model 3: Involvement by dimension } \\
\hline & \multicolumn{4}{|c|}{$\begin{array}{c}\text { Equation A: } \\
\text { Scope of market presence } \\
\text { (InSales) }\end{array}$} & \multicolumn{4}{|c|}{$\begin{array}{c}\text { Equation B: } \\
\text { Scope of client collaboration } \\
\text { (InCust) }\end{array}$} & \multicolumn{4}{|c|}{$\begin{array}{c}\text { Equation C: } \\
\text { Scope of non- client collaboration } \\
\text { (InSupp) }\end{array}$} \\
\hline & \multicolumn{2}{|c|}{ Base model } & \multicolumn{2}{|c|}{ Full model } & \multicolumn{2}{|c|}{ Base model } & \multicolumn{2}{|c|}{ Full model } & \multicolumn{2}{|c|}{ Base model } & \multicolumn{2}{|c|}{ Full model } \\
\hline & Coeff. & SE & Coeff. & $S E$ & Coeff. & SE & Coeff. & SE & Coeff. & SE & Coeff. & SE \\
\hline \multicolumn{13}{|l|}{ Labour market regions } \\
\hline Centrality 1-3 & \multicolumn{2}{|c|}{ Reference } & \multicolumn{2}{|c|}{ Reference } & \multicolumn{2}{|c|}{ Reference } & \multicolumn{2}{|c|}{ Reference } & \multicolumn{2}{|c|}{ Reference } & \multicolumn{2}{|c|}{ Reference } \\
\hline Trondheim & $-0,023$ & 0,044 & $-0,080$ & $0,043^{*}$ & 0,071 & 0,046 & $-0,004$ & 0,045 & 0,097 & 0,056 & $-0,011$ & 0,052 \\
\hline Stavanger & 0,089 & $0,041^{* *}$ & 0,045 & 0,041 & $-0,026$ & 0,043 & $-0,046$ & 0,043 & 0,017 & 0,052 & $-0,031$ & 0,050 \\
\hline Bergen & $-0,031$ & 0,040 & $-0,117$ & $0,044 * * *$ & $-0,080$ & $0,041 *$ & $-0,072$ & 0,046 & $-0,065$ & 0,050 & $-0,095$ & 0,053 \\
\hline Capital N & $-0,049$ & 0,061 & $-0,078$ & 0,069 & $-0,021$ & 0,064 & 0,074 & 0,072 & 0,003 & 0,077 & 0,183 & $0,084^{* *}$ \\
\hline Capital W & 0,038 & 0,041 & 0,010 & 0,052 & 0,035 & 0,043 & 0,066 & 0,055 & 0,152 & $0,051^{* * *}$ & 0,232 & $0,064^{* * *}$ \\
\hline Capital C & $-0,005$ & 0,029 & $-0,036$ & 0,044 & 0,017 & 0,030 & 0,057 & 0,046 & 0,087 & $0,036^{* *}$ & 0,189 & $0,053^{* * *}$ \\
\hline \multicolumn{13}{|l|}{ Firm characteristics } \\
\hline Medium (26-99 employees) & & & \multicolumn{2}{|c|}{ Reference } & \multicolumn{4}{|c|}{ Reference } & & & \multicolumn{2}{|c|}{ Reference } \\
\hline Small (<26 employees) & & & 0,004 & 0,034 & & & $-0,002$ & 0,035 & & & 0,036 & 0,041 \\
\hline Large (>99 employees) & & & $-0,001$ & 0,068 & & & $-0,094$ & 0,072 & & & $-0,102$ & 0,083 \\
\hline Part of foreign corporate group & & & 0,109 & $0,039 * * *$ & & & $-0,015$ & 0,041 & & & $-0,066$ & 0,048 \\
\hline \multicolumn{13}{|l|}{ Firm strategy } \\
\hline Innovation intensity & & & 0,019 & $0,048^{* * *}$ & & & 0,015 & $0,051^{* * *}$ & & & 0,015 & $0,059 * *$ \\
\hline IPR breadth & & & 0,108 & $0,049 * *$ & & & 0,211 & $0,052^{* * *}$ & & & 0,307 & $0,060^{* * *}$ \\
\hline Public funding & & & 0,014 & 0,035 & & & 0,126 & $0,036 * * *$ & & & 0,219 & $0,042^{* * *}$ \\
\hline \multicolumn{13}{|l|}{ Selection instruments } \\
\hline Age (log) & $-0,008$ & 0,013 & 0,000 & 0,013 & 0,009 & 0,014 & 0,004 & 0,014 & $-0,010$ & 0,017 & $-0,022$ & 0,016 \\
\hline Growth (log) & 0,000 & 0,026 & 0,030 & 0,026 & 0,034 & 0,028 & 0,030 & 0,027 & 0,037 & 0,033 & 0,040 & 0,032 \\
\hline Pseudo R2 & \multicolumn{2}{|c|}{0,0355} & \multirow{2}{*}{\multicolumn{2}{|c|}{0,1491}} & \multirow{2}{*}{\multicolumn{2}{|c|}{0,0202}} & \multicolumn{2}{|c|}{0,1304} & \multicolumn{2}{|c|}{0,0366} & \multicolumn{2}{|c|}{0,2113} \\
\hline Chi2 & & 7,73 & & ,61 & & & & 0,59 & & 5,49 & & 9,76 \\
\hline Prob $>$ Chi2 & & 006 & & 00 & 0,1 & & & 000 & & 004 & & 000 \\
\hline
\end{tabular}


Herstad \& Ebersberger, May 2013

Table 2: Involvement by geography

\begin{tabular}{|c|c|c|c|c|c|c|c|c|c|c|c|}
\hline \multicolumn{12}{|c|}{ Model 4: Involvement by geography } \\
\hline \multicolumn{4}{|c|}{$\begin{array}{c}\text { Equation A: } \\
\text { Breadth of local involvement } \\
\text { (InReg) }\end{array}$} & \multicolumn{4}{|c|}{$\begin{array}{c}\text { Equation B: } \\
\text { Breadth of domestic (nonlocal) involvement } \\
\text { (InDom) }\end{array}$} & \multicolumn{4}{|c|}{$\begin{array}{c}\text { Equation C: } \\
\text { Breadth of foreign involvement } \\
\text { (InFor) }\end{array}$} \\
\hline \multicolumn{2}{|c|}{ Base model } & \multicolumn{2}{|c|}{ Full model } & \multicolumn{2}{|c|}{ Base model } & \multicolumn{2}{|c|}{ Full model } & \multicolumn{2}{|c|}{ Base model } & \multicolumn{2}{|c|}{ Full model } \\
\hline Coeff. & SE & Coeff. & SE & Coeff. & SE & Coeff. & SE & Coeff. & SE & Coeff. & SE \\
\hline \multicolumn{2}{|c|}{ Reference } & \multicolumn{2}{|c|}{ Reference } & \multicolumn{2}{|c|}{ Reference } & \multicolumn{2}{|c|}{ Reference } & \multicolumn{2}{|c|}{ Reference } & \multicolumn{2}{|c|}{ Reference } \\
\hline 0,120 & $0,059^{* *}$ & 0,038 & 0,057 & $-0,013$ & 0,053 & $-0,111$ & $0,051^{* *}$ & 0,074 & 0,053 & $-0,026$ & 0,050 \\
\hline$-0,048$ & 0,056 & $-0,074$ & 0,054 & $-0,065$ & 0,050 & $-0,105$ & $0,049 * *$ & $-0,020$ & 0,050 & $-0,053$ & 0,048 \\
\hline$-0,051$ & 0,053 & $-0,069$ & 0,058 & $-0,088$ & $0,047^{*}$ & $-0,094$ & $0,052^{*}$ & $-0,083$ & $0,048^{*}$ & $-0,082$ & 0,052 \\
\hline$-0,006$ & 0,082 & 0,152 & $0,092^{*}$ & $-0,069$ & 0,073 & 0,065 & 0,081 & 0,012 & 0,074 & 0,144 & $0,081^{*}$ \\
\hline 0,139 & $0,054^{* *}$ & 0,194 & $0,070^{* * *}$ & $-0,013$ & 0,049 & 0,021 & 0,062 & 0,114 & $0,049 * *$ & 0,183 & $0,062^{* * *}$ \\
\hline 0,037 & 0,038 & 0,121 & $0,059 * *$ & $-0,063$ & $0,034 *$ & $-0,010$ & 0,052 & 0,073 & $0,034^{* *}$ & 0,148 & $0,052 * * *$ \\
\hline
\end{tabular}

\begin{tabular}{lclll} 
Labour market regions & \multicolumn{2}{c}{ Reference } & \multicolumn{2}{c}{ Reference } \\
Centrality 1-3 & 0,120 & $0,059^{* *}$ & 0,038 & 0,057 \\
Trondheim & $-0,048$ & 0,056 & $-0,074$ & 0,054 \\
Stavanger & $-0,051$ & 0,053 & $-0,069$ & 0,058 \\
Bergen & $-0,006$ & 0,082 & 0,152 & $0,092^{*}$ \\
Capital N & 0,139 & $0,054^{* *}$ & 0,194 & $0,070^{* * *}$ \\
Capital W & 0,037 & 0,038 & 0,121 & $0,059^{* *}$ \\
Capital C & & & & \\
Firm characteristics & & & $-0,019$ & 0,045 \\
Medium (26-99 employees) & & & $-0,093$ & 0,091 \\
Small (<26 employees) & & & $-0,059$ & 0,053 \\
Large (>99 employees) & & & & \\
Foreign corporate group & & & 0,014 & $0,064^{* *}$ \\
Firm strategy & & & 0,179 & $0,066^{* * *}$ \\
Innovation intensity & & 0,240 & $0,046^{* * *}$ \\
IPR breadth & & & \\
Public funding & & & 0,034 & 0,029 \\
Market presence & & &
\end{tabular}

Domestic

Foreign

Selection instruments

Age (log)

$-0,018 \quad 0,018$

Growth (log)

$0,021 \quad 0,035$

$0,026 \quad 0,035$

0,025

0,151

0,063

118,78
0,000

$-0,010 \quad 0,052$

Reference

$0,067 \quad 0,040^{*}$

$0,004 \quad 0,040$

$0,017 \quad 0,081$

$-0,053 \quad 0,081$

$-0,019 \quad 0,047$

$-0,011 \quad 0,047$

$0,014 \quad 0,057^{* *}$

$0,2420,058^{* * *}$

$0,020 \quad 0,058^{* * *}$

$0,167 \quad 0,041^{* *}$

$0,2610,059 * * *$

$0,156 \quad 0,041^{* * *}$

Prob>Chi2

0,000

0,026
17,88

$0,040 \quad 0,023 *$

Note: $\mathrm{N}=671$. Coefficient estimates and standard errors from seemingly unrelated regressions. Breusch-Pagan test of independence: Chi2 (3) $=328,543$, prob>Chi2 $=0,000$. $* * * * * *$ and $*$ indicate

significance at 1, 5 and 10 per cent levels respectively. Inverse Mills ratios calculated on the basis for model 1 and 2 are included in all regressions. The full regression models include three subsector controls, which are jointly significant. 
Herstad \& Ebersberger, May 2013

Table A1: Selection models

\begin{tabular}{|c|c|c|c|c|}
\hline \multirow[b]{3}{*}{ Centrality 1-4 } & \multicolumn{2}{|c|}{$\begin{array}{l}\text { Model 1: } \\
\text { Single=1 }\end{array}$} & \multicolumn{2}{|c|}{$\begin{array}{l}\text { Model 2: } \\
\text { Active=1 }\end{array}$} \\
\hline & Marg.eff & SE & Marg.eff & SE \\
\hline & \multicolumn{2}{|c|}{ Reference } & \multicolumn{2}{|c|}{ Reference } \\
\hline Trondheim & $-0,006$ & 0,041 & 0,013 & 0,077 \\
\hline Stavanger & $-0,003$ & 0,036 & 0,107 & 0,072 \\
\hline Bergen & $-0,013$ & 0,040 & 0,207 & $0,069 * * *$ \\
\hline Capital & 0,250 & $0,022 * * *$ & $-0,220$ & $0,104 * *$ \\
\hline Part of foreign corporate group & & & $-0,114$ & 0,071 \\
\hline Foreign market orientation & & & 0,216 & $0,047 * * *$ \\
\hline Size $(\log )$ & $-0,117$ & $0,009 * * *$ & 0,138 & $0,051 * * *$ \\
\hline Age (log) & $-0,029$ & $0,012 * *$ & 0,023 & 0,024 \\
\hline Growth (log) & & & $-0,080$ & $0,042^{*}$ \\
\hline $\mathrm{N}$ & \multicolumn{2}{|c|}{2359} & \multicolumn{2}{|c|}{1144} \\
\hline Wald Chi2(9) & \multicolumn{2}{|c|}{375,24} & \multicolumn{2}{|c|}{143,32} \\
\hline Prob $>$ Chi2 & \multicolumn{2}{|c|}{0,000} & \multicolumn{2}{|c|}{0,000} \\
\hline Pseudo R2 & \multicolumn{2}{|c|}{0,179} & \multicolumn{2}{|c|}{0,121} \\
\hline \multicolumn{5}{|c|}{$\begin{array}{l}\text { Note: Marginal effects and robust standard errors from probit regression model. }{ }^{* * *},{ }^{* *} \text { and }{ }^{*} \text { indicate significance at } 1,5 \\
\text { and } 10 \text { per cent levels respectively. Both models include three subsector controls, which are jointly significant. Model } 2 \\
\text { include the inverse Mills ratio calculated on the basis of Model } 1 .\end{array}$} \\
\hline
\end{tabular}


Herstad \& Ebersberger, May 2013

Table A2: Descriptive statistics and correlations

\begin{tabular}{|c|c|c|c|c|c|c|c|c|c|c|c|c|c|c|c|c|c|c|c|c|c|c|c|c|c|c|c|c|c|c|c|}
\hline & & Mean & SD & Max & 1 & 2 & 3 & 4 & 5 & 6 & 7 & 8 & 9 & 10 & 11 & 12 & 13 & 14 & 15 & 16 & 17 & 18 & 19 & 20 & 21 & 22 & 23 & 24 & 25 & 26 & 27 \\
\hline 1 & Sales inv. (log) & 0,55 & 0,27 & 1,30 & 1 & & & & & & & & & & & & & & & & & & & & & & & & & & \\
\hline 2 & Client inv. (log) & 0,09 & 0,28 & 1,91 & 0,19 & 1 & & & & & & & & & & & & & & & & & & & & & & & & & \\
\hline 3 & Non-cl inv. (log) & 0,15 & 0,34 & 1,71 & 0,17 & 0,63 & 1 & & & & & & & & & & & & & & & & & & & & & & & & \\
\hline 4 & Regional inv. (log) & 0,13 & 0,35 & 2,03 & 0,10 & 0,62 & 0,69 & 1 & & & & & & & & & & & & & & & & & & & & & & & \\
\hline 5 & Domestic inv. (log) & 0,10 & 0,32 & 2,02 & 0,15 & 0,59 & 0,63 & 0,45 & 1 & & & & & & & & & & & & & & & & & & & & & & \\
\hline 6 & Foreign inv. (log) & 0,10 & 0,32 & 1,90 & 0,19 & 0,69 & 0,83 & 0,46 & 0,53 & 1 & & & & & & & & & & & & & & & & & & & & & \\
\hline 7 & Trondheim & 0,06 & 0,24 & 1 & $-0,02$ & 0,07 & 0,06 & 0,08 & 0,04 & 0,05 & 1 & & & & & & & & & & & & & & & & & & & & \\
\hline 8 & Stavanger & 0,08 & 0,27 & 1 & 0,13 & $-0,01$ & 0,01 & $-0,04$ & $-0,01$ & $-0,02$ & $-0,08$ & 1 & & & & & & & & & & & & & & & & & & & \\
\hline 9 & Bergen & 0,09 & 0,29 & 1 & $-0,01$ & $-0,07$ & $-0,07$ & $-0,04$ & $-0,03$ & $-0,08$ & $-0,08$ & $-0,09$ & 1 & & & & & & & & & & & & & & & & & & \\
\hline 10 & Capital N & 0,03 & 0,18 & 1 & $-0,06$ & $-0,03$ & $-0,06$ & $-0,04$ & $-0,03$ & $-0,04$ & $-0,05$ & $-0,05$ & $-0,06$ & 1 & & & & & & & & & & & & & & & & & \\
\hline 11 & Capital W & 0,10 & 0,29 & 1 & 0,03 & 0,02 & 0,06 & 0,08 & 0,00 & 0,05 & $-0,08$ & $-0,09$ & $-0,10$ & $-0,06$ & 1 & & & & & & & & & & & & & & & & \\
\hline 12 & Capital C & 0,34 & 0,47 & 1 & $-0,05$ & 0,00 & 0,02 & $-0,02$ & $-0,09$ & 0,04 & $-0,19$ & $-0,21$ & $-0,23$ & $-0,13$ & $-0,23$ & 1 & & & & & & & & & & & & & & & \\
\hline 13 & Postal \& Com. Serv. & 0,06 & 0,24 & 1 & 0,01 & $-0,08$ & $-0,05$ & $-0,06$ & $-0,07$ & $-0,04$ & $-0,04$ & $-0,05$ & $-0,03$ & 0,06 & $-0,02$ & $-0,04$ & 1 & & & & & & & & & & & & & & \\
\hline 14 & Financial services & 0,09 & 0,28 & 1 & $-0,07$ & $-0,05$ & $-0,05$ & $-0,05$ & $-0,09$ & $-0,05$ & $-0,04$ & $-0,08$ & $-0,05$ & 0,12 & $-0,06$ & 0,10 & $-0,08$ & 1 & & & & & & & & & & & & & \\
\hline 15 & Technical services & 0,41 & 0,49 & 1 & $-0,03$ & 0,00 & $-0,04$ & $-0,04$ & $-0,04$ & 0,00 & 0,00 & 0,02 & $-0,07$ & $-0,08$ & 0,00 & 0,12 & $-0,21$ & $-0,26$ & 1 & & & & & & & & & & & & \\
\hline 16 & Other services & 0,44 & 0,50 & 1 & 0,07 & 0,06 & 0,09 & 0,09 & 0,12 & 0,04 & 0,04 & 0,05 & 0,11 & $-0,02$ & 0,05 & $-0,16$ & $-0,22$ & $-0,27$ & $-0,74$ & 1 & & & & & & & & & & & \\
\hline 17 & Local market & 0,24 & 0,43 & 1 & 0,30 & 0,00 & $-0,01$ & 0,01 & 0,01 & $-0,02$ & $-0,07$ & 0,00 & 0,04 & $-0,04$ & $-0,05$ & $-0,14$ & 0,06 & 0,04 & $-0,07$ & 0,02 & 1 & & & & & & & & & & \\
\hline 18 & Domestic market & 0,75 & 0,44 & 1 & $-0,03$ & 0,11 & 0,06 & 0,04 & 0,07 & 0,06 & 0,03 & 0,05 & 0,02 & $-0,02$ & 0,02 & 0,09 & 0,03 & $-0,09$ & 0,06 & $-0,03$ & $-0,55$ & 1 & & & & & & & & & \\
\hline 19 & Foreign market & 0,53 & 0,50 & 1 & 0,70 & 0,18 & 0,16 & 0,08 & 0,14 & 0,20 & 0,02 & 0,08 & $-0,04$ & $-0,04$ & 0,07 & 0,08 & $-0,08$ & $-0,15$ & 0,13 & 0,00 & $-0,30$ & 0,19 & 1 & & & & & & & & \\
\hline 20 & Small (<26 emp) & 0,73 & 0,44 & 1 & $-0,07$ & $-0,08$ & $-0,14$ & $-0,14$ & $-0,10$ & $-0,08$ & 0,02 & 0,02 & 0,09 & 0,09 & $-0,13$ & $-0,13$ & $-0,05$ & $-0,07$ & 0,04 & 0,03 & 0,09 & $-0,09$ & $-0,12$ & 1 & & & & & & & \\
\hline 21 & Medium (26-99 emp) & 0,24 & 0,43 & 1 & 0,06 & 0,08 & 0,12 & 0,13 & 0,07 & 0,06 & $-0,02$ & $-0,02$ & $-0,09$ & $-0,09$ & 0,13 & 0,10 & 0,05 & 0,04 & $-0,03$ & $-0,02$ & $-0,08$ & 0,08 & 0,11 & $-0,93$ & 1 & & & & & & \\
\hline 22 & Large (>99 emp) & 0,03 & 0,17 & 1 & 0,03 & 0,01 & 0,07 & 0,04 & 0,08 & 0,06 & 0,01 & 0,02 & $-0,02$ & $-0,01$ & 0,01 & 0,08 & 0,00 & 0,07 & $-0,01$ & $-0,03$ & $-0,03$ & 0,03 & 0,04 & $-0,29$ & $-0,10$ & 1 & & & & & \\
\hline 23 & Foreign corp. Group & 0,07 & 0,26 & 1 & 0,07 & 0,01 & $-0,01$ & 0,00 & 0,02 & 0,03 & 0,01 & $-0,05$ & $-0,07$ & $-0,02$ & 0,08 & 0,09 & $-0,04$ & 0,01 & $-0,01$ & 0,02 & $-0,07$ & $-0,01$ & 0,11 & $-0,24$ & 0,18 & 0,19 & 1 & & & & \\
\hline 24 & Innovation intensity & 163,71 & 233,18 & 773,69 & 0,22 & 0,21 & 0,21 & 0,18 & 0,16 & 0,25 & 0,15 & $-0,04$ & $-0,08$ & $-0,02$ & $-0,05$ & 0,10 & $-0,08$ & $-0,17$ & 0,22 & $-0,08$ & $-0,12$ & $-0,02$ & 0,30 & 0,11 & $-0,10$ & $-0,04$ & $-0,01$ & 1 & & & \\
\hline 25 & IPR breadth & 0,15 & 0,22 & 1 & 0,22 & 0,25 & 0,32 & 0,22 & 0,24 & 0,30 & 0,10 & 0,11 & $-0,04$ & $-0,10$ & 0,03 & 0,07 & $-0,06$ & $-0,10$ & 0,09 & 0,00 & $-0,08$ & 0,00 & 0,27 & $-0,16$ & 0,13 & 0,09 & 0,06 & 0,29 & 1 & & \\
\hline 26 & Public funding & 0,10 & 0,30 & 1 & 0,09 & 0,20 & 0,26 & 0,26 & 0,22 & 0,22 & 0,10 & $-0,06$ & 0,04 & $-0,06$ & 0,04 & $-0,08$ & $-0,06$ & $-0,10$ & 0,00 & 0,09 & $-0,09$ & 0,09 & 0,13 & 0,00 & 0,01 & $-0,02$ & $-0,04$ & 0,31 & 0,11 & 1 & \\
\hline 27 & Age $(\log )$ & 2,16 & 0,84 & 3,81 & $-0,03$ & 0,02 & $-0,01$ & $-0,01$ & 0,06 & 0,02 & 0,07 & $-0,04$ & $-0,04$ & 0,07 & $-0,07$ & 0,00 & $-0,03$ & 0,06 & $-0,07$ & 0,05 & 0,09 & 0,00 & $-0,08$ & $-0,08$ & 0,05 & 0,09 & 0,09 & $-0,13$ & 0,01 & $-0,06$ & 1 \\
\hline 28 & Growth (log) & 0,61 & 0,41 & 3,38 & $-0,01$ & 0,02 & 0,03 & 0,01 & $-0,01$ & 0,04 & $-0,06$ & 0,02 & 0,02 & $-0,04$ & 0,00 & 0,01 & 0,06 & $-0,01$ & 0,00 & $-0,02$ & 0,01 & $-0,07$ & 0,00 & 0,06 & $-0,04$ & $-0,06$ & $-0,05$ & 0,03 & 0,00 & 0,00 & $-0,32$ \\
\hline
\end{tabular}

Note: Bivariate correlations and descriptive statistics, innovation active establishments ( $\mathrm{N}=671)$. The minimum value of all variables is zero. Innovation intensity is reported in NOK 1000 . 


\footnotetext{
'As an example of how involvement indexes are constructed, consider a firm engaged in client collaboration only in the Nordic coutries and in Asia. In the NACE 2-digit sector of this firm, collaboration with customers within the Nordic countries is rather common as $80 \%$ of the firms maintain such. Collaboration with customers in the EU is maintained by $65 \%$, in North America by $60 \%$, in Asia by $25 \%$ and elsewhere by $30 \%$. Before logarithimic transformation, the scope of client involvement would be:

$$
(1 *(1-0.80))+(0 *(1-0.65))+(0 *(1-0.60))+(1 *(1-0.25))+(0 *(1-0.30))=0.95
$$

Similarly, consider a firm in a sector where $50 \%$ collaborate with clients locally; $15 \%$ do so with suppliers locally and $7 \%$ with research institutes locally. The average for local collaboration with universities, competitors, consultancy firms and private R\&D labs is $1 \%$ in all cases. If this single firm maintains local client collaboration, supplier collaboration and university collaboration, the breadth of local involvement would be 2.34 before log transformation. If the same firm also collaborates with a local research institute, the involvement score would increase by $1 *(1-0.07)$, i.e. by 0.93 .
} 


\section{CIRCLE ELECTRONIC WORKING PAPERS SERIES (EWP)}

CIRCLE (Centre for Innovation, Research and Competence in the Learning Economy) is a multidisciplinary research centre set off by several faculties at Lund University and Blekinge Institute of Technology. CIRCLE has a mandate to conduct multidisciplinary research and education on the following issues: Long-term perspectives on innovation, structural change and economic growth, Entrepreneurship and venture capital formation with a special focus on new ventures, The dynamics of R\&D systems and technological systems, including their impact on entrepreneurship and growth, Regional innovation systems in different national and international contexts and International comparative analyses of national innovation systems. Special emphasis is done on innovation policies and research policies. 10 nationalities and 14 disciplines are represented among the CIRCLE staff.

The CIRCLE Electronic Working Paper Series are intended to be an instrument for early dissemination of the research undertaken by CIRCLE researchers, associates and visiting scholars and stimulate discussion and critical comment.

The working papers present research results that in whole or in part are suitable for submission to a refereed journal or to the editor of a book or have already been submitted and/or accepted for publication.

CIRCLE EWPs are available on-line at: http:// http://www.circle.lu.se/?page_id=176

Available papers:

$\underline{2013}$

WP 2013/01

Start-up rates, Entrepreneurship Culture and the Business Cycle Swedish patterns from national and regional data Martin Andersson

WP 2013/02

Market Thickness and the Early Labor Market Career of University Graduates -An urban advantage?

Lina Ahlin, Martin Andersson and Per Thulin

WP 2013/03

Implementing an R\&D Strategy without Prior R\&D-Experience - Recruitment as a Source of R\&D-related Routines and Capabilities?

Lina Ahlin, Martin Andersson and Thorben Schubert

WP 2013/04

The Choice of Innovation Policy Instruments

Susana Borrás, Charles Edquist

WP 2013/05

What Does Evolutionary Economic Geography Bring To The Policy Table? Reconceptualising regional innovation systems Bjørn Asheim, Markus M. Bugge, Lars Coenen, Sverre Herstad

WP 2013/06

Commercializing clean technology innovations - the emergence of new business in an agency-structure perspective Sofia Avdeitchikova, Lars Coenen

WP 2013/07

Renewal of mature industry in an old industrial region: regional innovation policy and the co-evolution of institutions and technology Lars Coenen, Jerker Moodysson and Hanna Martin

WP 2013/08

Systematic anchoring of global innovation processes and new industry formation - the emergence of on-site water recycling in China Christian Binz, Bernhard Truffer and Lars Coenen

WP 2013/09

The internationalisation of R\&D: sectoral and geographic patterns of cross-border investments Cristina Castelli and Davide Castellani

WP 2013/10

Clean-tech innovation in Emerging Economies: Transnational dimensions in technological innovation system formation Jorrit Gosens, Yonglong Lu and Lars Coenen

WP 2013/11

Why space matters in technological innovation systems - the global knowledge dynamics of membrane bioreactor technology Christian Binz, Bernhard Truffer and Lars Coenen

WP 2013/12

MNC affiliation, knowledge bases and involvement in global innovation networks

Sverre J. Herstad, Bernd Ebersberger, Bjørn Asheim

WP 2013/13

System Failures, Knowledge Bases and Regional Innovation Policies

Roman Martin and Michaela Trippl

WP 2013/14

Differentiated Knowledge Bases and the Nature of Innovation Networks

Roman Martin

WP 2013/15

The Geography and Structure of Global Innovation Networks: A Knowledge Base Perspective

Ju Liu; Cristina Chaminade; Bjørn Asheim

WP 2013/16

The spatiality of trust - Antecedents of trust and the role of face-to-face contacts 
WP 2013/17

Technology-Driven FDI: A Survey of the Literature

Technology-Driven FDl: A Survey of the Literature
Alessia Amighini; Claudio Cozza; Elisa Giuliani; Roberta Rabellotti; Vittoria Scalera

WP 2013/18

Substitution or overlap? The relations between geographical and non-spatial proximity dimensions in collaborative innovation projects Teis Hansen

WP 2013/19

Entrepreneurship and the Business Cycle: Do New Technology-Based Firms Differ?

Olof Ejermo and Jing Xiao

WP 2013/20

R\&D offshoring and the productivity growth of European regions

Davide Castellani and Fabio Pieri

WP 2013/21

On the link between urban location and the involvement of knowledge intensive business services firms in collaboration networks

Sverre J. Herstad and Bernd Ebersberger

\section{2}

WP 2012/01

Is the University Model an Organizational Necessity? Scale and Agglomeration Effects in Science

Tasso Brandt and Torben Schubert

WP 2012/02

Do regions make a difference? Exploring the role of different regional innovation systems in global innovation networks in the ICT industry Cristina Chaminade and Monica Plechero

WP 2012/03

Measuring the knowledge base of regional innovation systems in Sweden

Roman Martin

WP 2012/04

Characteristics and Performance of New Firms and Spinoffs in Sweden

Martin Andersson and Steven Klepper

WP 2012/05

Demographic patterns and trends in patenting: Gender, age, and education of inventors

Olof Ejermo and Taehyun Jung

WP 2012/06

Competences as drivers and enablers of globalization of innovation: Swedish ICT industry and emerging economies

Cristina Chaminade and Claudia de Fuentes

WP 2012/07

The Dynamics and Evolution of Local Industries - The case of Linköping

Sabrina Fredin

WP2012/08

Towards a Richer Specification of the Exploration/Exploitation Trade-off: Hidden Knowledge-based Aspects and Empirical Results for a Set of Large R\&D-Performing Firms

Torben Schubert and Peter Neuhaeusle

WP 2012/09

The European Spallation Source (ESS) and the geography of innovation

Josephine V. Rekers

WP 2012/10

How Local are Spatial Density Externalities? - $\quad$ evidence from square grid data

Martin Andersson, Johan Klaesson, Johan P Larsson

WP 2012/11

Why Pre-Commercial Procurement is not Innovation Procurement

Charles Edquist, Jon Mikel Zabala-Iturriagagoitia

\section{1}

WP 2011/01

SMEs' absorptive capacities and large firms' knowledge spillovers: Micro evidence from Mexico Claudia de Fuentes and Gabriela Dutrénit

WP 2011/02

Comparing knowledge bases: on the organisation and geography of knowledge flows in the regional innovation system of Scania, southern Sweden

Roman Martin and Jerker Moodysson

WP 2011/03

Organizational paths of commercializing patented inventions: The effects of transaction costs, firm capabilities, and collaborative ties Taehyun Jung and John P. Walsh

WP 2011/04

Global Innovation Networks: towards a taxonomy

Helena Barnard and Cristina Chaminade

WP 2011/05

Swedish Business R\&D and its Export Dependence

Karin Bergman and Olof Ejermo

WP 2011/06

Innovation Policy Design: Identification of Systemic Problems 
Charles Edquist

WP 2011/07

Regional Institutional Environment and Its Impact on Intra-firm and Inter-organisational Innovation Networks: A Comparative Case Study in China and Switzerland

Ju LIU

WP 2011/08

Entrepreneurship: Exploring the Knowledge Base

Hans Landström, Gouya Harirchi and Fredrik Åström

WP 2011/09

Policy coordination in systems of innovation: A structural-functional analysis of regional industry support in Sweden

Magnus Nilsson and Jerker Moodysson

WP 2011/10

Urban Design in Neighbourhood Commodification

Ana Mafalda Madureira

WP 2011/11

Technological Dynamics and Social Capability: Comparing U.S. States and European Nations

Jan Fagerberg, Maryan Feldman and Martin Srhoelec

WP 2011/12

Linking scientific and practical knowledge in innovation systems

Arne Isaksen and Magnus Nilsson

WP 2011/13

Institutional conditions and innovation systems: on the impact of regional policy on firms in different sectors Jerker Moodysson and Elena Zukauskaite

WP 2011/14

Considering adoption: Towards a consumption-oriented approach to innovation

Josephine V. Rekers

WP2011/15

Exploring the role of regional innovation systems and institutions in global innovation networks

Cristina Chaminade

\section{0}

WP 2010/01

Innovation policies for development: towards a systemic experimentation based approach

Cristina Chaminade, Bengt-Ake Lundvall, Jan Vang-Lauridsen and KJ Joseph

WP 2010/02

From Basic Research to Innovation: Entrepreneurial Intermediaries for Research Commercialization at Swedish 'Strong Research Environments' Fumi Kitagawa and Caroline Wigren

WP 2010/03 Different competences, different modes in the globalization of innovation? A comparative study of the Pune and Beijing regions Monica Plechero and Cristina Chaminade

WP 2010/04 Technological Capability Building in Informal Firms in the Agricultural Subsistence Sector In Tanzania: Assessing the Role of Gatsby Clubs

Astrid Szogs and Kelefa Mwantima

WP 2010/05

The Swedish Paradox - Unexploited Opportunities

Charles Edquist

WP 2010/06

A three-stage model of the Academy-Industry linking process: the perspective of both agents

Claudia De Fuentes and Gabriela Dutrénit

WP 2010/07

Innovation in symbolic industries: the geography and organisation of knowledge sourcing

Roman Martin and Jerker Moodysson

WP 2010/08

Towards a spatial perspective on sustainability transitions

Lars Coenen, Paul Benneworth and Bernhard Truffer

WP 2010/09

The Swedish national innovation system and its relevance for the emergence of global innovation networks

Cristina Chaminade, Jon Mikel Zabala and Adele Treccan

WP 2010/10

Who leads Research Productivity Change? Guidelines for R\&D policy makers

Fernando Jiménez-Sáez, Jon Mikel Zabala and José L- Zofío

WP 2010/11

Research councils facing new science and technology

Frank van der Most and Barend van der Meulen

WP 2010/12

Effect of geographical proximity and technological capabilities on the degree of novelty in emerging economies Monica Plechero

WP 2010/13

Are knowledge-bases enough? A comparative study of the geography of knowledge sources in China (Great Beijing) and India (Pune) Cristina Chaminade

WP 2010/14

Regional Innovation Policy beyond 'Best Practice': Lessons from Sweden

Roman Martin, Jerker Moodysson and Elena Zukauskaite

WP 2010/15 
Innovation in cultural industries: The role of university links

Elena Zukauskaite

WP 2010/16

Use and non-use of research evaluation. A literature review

Frank van der Most

WP 2010/17

Upscaling emerging niche technologies in sustainable energy: an international comparison of policy approaches

Lars Coenen, Roald Suurs and Emma van Sandick

\section{9}

WP 2009/01

Building systems of innovation in less developed countries: The role of

intermediate organizations.

Szogs, Astrid; Cummings, Andrew and Chaminade, Cristina

WP 2009/02

The Widening and Deepening of Innovation Policy: What Conditions Provide for Effective Governance?

Borrás, Susana

WP 2009/03

Managerial learning and development in small firms: implications based on observations of managerial work Gabrielsson, Jonas and Tell, Joakim

WP 2009/04

University professors and research commercialization: An empirical test of the "knowledge corridor" thesis Gabrielsson, Jonas, Politis, Diamanto and Tell, Joakim

WP 2009/05

On the concept of global innovation networks

Chaminade, Cristina

WP 2009/06

Technological Waves and Economic Growth - Sweden in an International Perspective 1850-2005

Schön, Lennart

WP 2009/07

Public Procurement of Innovation Diffusion: Exploring the Role of Institutions and Institutional Coordination

Rolfstam, Max; Phillips, Wendy and Bakker, Elmer

WP 2009/08

Local niche experimentation in energy transitions: a theoretical and empirical exploration of proximity advantages and disadvantages Lars Coenen, Rob Raven, Geert Verbong

WP 2009/9

Product Development Decisions: An empirical approach to Krishnan and Ulrich

Jon Mikel Zabala, Tina Hannemann

WP 2009/10

Dynamics of a Technological Innovator Network and its impact on technological performance

Ju Liu, Cristina Chaminade

WP 2009/11

The Role of Local Universities in Improving Traditional SMEs Innovative Performances: The Veneto Region Case

Monica Plechero

WP 2009/12

Comparing systems approaches to innovation and technological change for sustainable and competitive economies: an explorative study into conceptual commonalities, differences and complementarities

Coenen, Lars and Díaz López, Fernando J.

WP 2009/13

Public Procurement for Innovation (PPI) - a Pilot Study

Charles Edquist

WP 2009/14

Outputs of innovation systems: a European perspective

Charles Edquist and Jon Mikel Zabala

\section{8}

WP 2008/01

$R \& D$ and financial systems: the determinants of $R \& D$ expenditures in the Swedish pharmaceutical industry

Malmberg, Claes

WP 2008/02

The Development of a New Swedish Innovation Policy. A Historical Institutional Approach

Persson, Bo

WP 2008/03

The Effects of R\&D on Regional Invention and Innovation

Olof Ejermo and Urban Gråsjö

WP 2008/04

Clusters in Time and Space: Understanding the Growth and Transformation of

Life Science in Scania

Moodysson, Jerker; Nilsson, Magnus; Svensson Henning, Martin

WP 2008/05

Building absorptive capacity in less developed countries

The case of Tanzania

Szogs, Astrid; Chaminade, Cristina and Azatyan, Ruzana

WP 2008/06

Design of Innovation Policy through Diagnostic Analysis:

Identification of Systemic Problems (or Failures) 
Edquist, Charles

WP 2008/07

The Swedish Paradox arises in Fast-Growing Sectors

Ejermo, Olof; Kander, Astrid and Svensson Henning, Martin

WP 2008/08

Policy Reforms, New University-Industry Links and Implications for Regional Development in Japan

Kitagawa, Fumi

WP 2008/09

The Challenges of Globalisation: Strategic Choices for Innovation Policy

Borrás, Susana; Chaminade, Cristina and Edquist, Charles

WP 2008/10

Comparing national systems of innovation in Asia and Europe: theory and comparative framework

Edquist, Charles and Hommen, Leif

WP 2008/11

Putting Constructed Regional Advantage into Swedish Practice? The case of the VINNVÄXT initiative 'Food Innovation at Interfaces'

Coenen, Lars; Moodysson, Jerker

WP 2008/12

Energy transitions in Europe: $1600-2000$

Kander, Astrid; Malanima, Paolo and Warde, Paul

WP 2008/13

RIS and Developing Countries: Linking firm technological capabilities to regional systems of innovation

Padilla, Ramon; Vang, Jan and Chaminade, Cristina

WP 2008/14

The paradox of high R\&D input and low innovation output: Sweden

Bitarre, Pierre; Edquist, Charles; Hommen, Leif and Ricke, Annika

WP 2008/15

Two Sides of the Same Coin? Local and Global Knowledge Flows in Medicon Valley

Moodysson, Jerker; Coenen, Lars and Asheim, Bjørn

WP 2008/16

Electrification and energy productivity

Enflo, Kerstin; Kander, Astrid and Schön, Lennart

WP 2008/17

Concluding Chapter: Globalisation and Innovation Policy

Hommen, Leif and Edquist, Charles

WP 2008/18

Regional innovation systems and the global location of innovation activities: Lessons from Chin

Yun-Chung, Chen; Vang, Jan and Chaminade, Cristina

WP 2008/19

The Role of mediator organisations in the making of innovation systems in least developed countries. Evidence from Tanzania

Szogs, Astrid

WP 2008/20

Globalisation of Knowledge Production and Regional Innovation Policy:

Supporting Specialized Hubs in the Bangalore Software Industry

Chaminade, Cristina and Vang, Jan

WP 2008/21

Upgrading in Asian clusters: Rethinking the importance of interactive-learning

Chaminade, Cristina and Vang, Jan

\section{$\underline{2007}$}

\section{WP 2007/01}

Path-following or Leapfrogging in Catching-up: the Case of Chinese Telecommunication Equipment Industry Liu, Xielin

WP 2007/02

The effects of institutional change on innovation and productivity growth in the Swedish pharmaceutical industry Malmberg, Claes

WP 2007/03

Global-local linkages, Spillovers and Cultural Clusters: Theoretical and Empirical insights from an exploratory study of Toronto's Film Cluste Vang, Jan; Chaminade, Cristina

WP 2007/04

Learning from the Bangalore Experience: The Role of Universities in an Emerging Regional Innovation System

Vang, Jan; Chaminade, Cristina.; Coenen, Lars.

WP 2007/05

Industrial dynamics and innovative pressure on energy -Sweden with European and Global outlooks

Schön, Lennart; Kander, Astrid.

WP 2007/06

In defence of electricity as a general purpose technology

Kander, Astrid; Enflo, Kerstin; Schön, Lennart

WP 2007/07

Swedish business research productivity - improvements against international trends

Ejermo, Olof; Kander, Astrid

WP 2007/08

Regional innovation measured by patent data - does quality matter?

Ejermo, Olof

WP 2007/09 
Innovation System Policies in Less Successful Developing countries: The case of Thailand Intarakumnerd, Patarapong; Chaminade, Cristina

\section{6}

WP 2006/01

The Swedish Paradox

Ejermo, Olof; Kander, Astrid

WP 2006/02

Building RIS in Developing Countries: Policy Lessons from Bangalore, India

Vang, Jan; Chaminade, Cristina

WP 2006/03

Innovation Policy for Asian SMEs: Exploring cluster differences

Chaminade, Cristina; Vang, Jan.

WP 2006/04

Rationales for public intervention from a system of innovation approach: the case of VINNOVA.

Chaminade, Cristina; Edquist, Charles

WP 2006/05

Technology and Trade: an analysis of technology specialization and export flows

Andersson, Martin; Ejermo, Olof

\section{WP 2006/06}

A Knowledge-based Categorization of Research-based Spin-off Creation

Gabrielsson, Jonas; Landström, Hans; Brunsnes, E. Thomas

WP 2006/07

Board control and corporate innovation: an empirical study of small technology-based firms

Gabrielsson, Jonas; Politis, Diamanto

\section{WP 2006/08}

On and Off the Beaten Path:

Transferring Knowledge through Formal and Informal Networks

Rick Aalbers; Otto Koppius; Wilfred Dolfsma

WP 2006/09

Trends in R\&D, innovation and productivity in Sweden 1985-2002

Ejermo, Olof; Kander, Astrid

WP 2006/10

Development Blocks and the Second Industrial Revolution, Sweden 1900-1974

Enflo, Kerstin; Kander, Astrid; Schön, Lennart

WP 2006/11

The uneven and selective nature of cluster knowledge networks: evidence from

the wine industry

Giuliani, Elisa

WP 2006/12

Informal investors and value added: The contribution of investors' experientially acquired resources in the entrepreneurial process Politis, Diamanto; Gabrielsson, Jonas

WP 2006/13

Informal investors and value added: What do we know and where do we go?

Politis, Diamanto; Gabrielsson, Jonas

WP 2006/14

Inventive and innovative activity over time and geographical space: the case of

Sweden

Ejermo, Olof

\section{5}

WP 2005/1

Constructing Regional Advantage at the Northern Edge

Coenen, Lars; Asheim, Bjørn

WP 2005/02

From Theory to Practice: The Use of the Systems of Innovation Approach for Innovation Policy Chaminade, Cristina; Edquist, Charles

WP 2005/03

The Role of Regional Innovation Systems in a Globalising Economy: Comparing Knowledge Bases and Institutional Frameworks in Nordic Clusters

Asheim, Bjørn; Coenen, Lars

WP 2005/04

How does Accessibility to Knowledge Sources Affect the Innovativeness of Corporations? Evidence from Sweden

Andersson, Martin; Ejermo, Olof

WP 2005/05

Contextualizing Regional Innovation Systems in a Globalizing Learning Economy: On Knowledge Bases and Institutional Frameworks Asheim, Bjørn; Coenen, Lars

WP 2005/06

Innovation Policies for Asian SMEs: An Innovation Systems Perspective

Chaminade, Cristina; Vang, Jan

WP 2005/07

Re-norming the Science-Society Relation

Jacob, Merle

WP 2005/08

Corporate innovation and competitive environment

Huse, Morten; Neubaum, Donald O.; Gabrielsson, Jonas 
WP 2005/09

Knowledge and accountability: Outside directors' contribution in the corporate value chain Huse, Morten, Gabrielsson, Jonas; Minichilli, Alessandro

WP 2005/10

Rethinking the Spatial Organization of Creative Industries

Vang, Jan

WP 2005/11

Interregional Inventor Networks as Studied by Patent Co-inventorships

Ejermo, Olof; Karlsson, Charlie

WP 2005/12

Knowledge Bases and Spatial Patterns of Collaboration: Comparing the Pharma and Agro-Food Bioregions Scania and Saskatoon Coenen, Lars; Moodysson, Jerker; Ryan, Camille; Asheim, Bjørn; Phillips, Peter

WP 2005/13

Regional Innovation System Policy: a Knowledge-based Approach

Asheim, Bjørn; Coenen, Lars; Moodysson, Jerker; Vang, Jan

WP 2005/14

Face-to-Face, Buzz and Knowledge Bases: Socio-spatial implications for learning and innovation policy

Asheim, Bjørn; Coenen, Lars, Vang, Jan

WP 2005/15

The Creative Class and Regional Growth: Towards a Knowledge Based Approach

Kalsø Hansen, Høgni; Vang, Jan; Bjørn T. Asheim

WP 2005/16

Emergence and Growth of Mjärdevi Science Park in Linköping, Sweden

Hommen, Leif; Doloreux, David; Larsson, Emma

WP 2005/17

Trademark Statistics as Innovation Indicators? - A Micro Study

Malmberg, Claes 